macza, Autor informuje czytelników, że wśród listów tego słowackiego przekładu nie ma, skądinąd interesującej, ale apokryficznej korespondencji Bazylego Wielkiego. Do tej zaś grupy Listów należą: korespondencja z retorem Libaniuszem (Ep. 335-359), Julianem Apostatą (Ep. 360), Apolinarym (Ep. 361-364), cesarzem Teodozjuszem Wielkim ( $E p$ 365) i mnichem Urbikonem (Ep. 366).

W tej samej nocie wydawniczej thumacz przyznaje, że przekład Hexaémero$n u$ przygotował wyłącznie dla serii wydawniczej „Bibliotheca Antiqua Christiana", tłumaczenia zaś dokonal z 2. wydania tekstu krytycznego S. Gieta, wydanego w „Sources Chrétiennes”, ${ }^{3}$. Dodaje również, że św. Bazyli w swoich homiliach przy cytowaniu i komentowaniu Starego Testamentu używał Septuaginty i oryginału Nowego Testamentu. Czytelnik słowacki otrzymał przez to od thmacza wyjaśnienie, że wprowadzone przez niego do przekładu cytaty biblijne nie będą wiernie odpowiadały oficjalnemu slowackiemu przekładowi Biblii z 1995 roku $^{4}$. Przez wydanie tego tomu kontynuowanej już serii patrystycznej, czytelnik słowacki dostał dalszą możność, by się zbliżyć i czerpać $\mathrm{z}$ duchowego bogactwa, którym w swoim czasie Ojcowie dzielili się ze współczesnymi.

Tadeusz Leander Pietras OSPPE - Vranov n/Topl'ou, Słowacja

\title{
Ks. Norbert WIDOK, Physis w pismach Grzegorza $z$ Nazjanzu. Studium z teologii patrystycznej, Opole 2001, Redakcja Wydawnictw Wydziału Teolo- gicznego UO, ss. 303.
}

Wśród pozycji związanych z myślą Ojców Kościoła, jakie ukazały się w ostatnim czasie, $\mathrm{z}$ dużą satysfakcją odnotowujemy te, które wiążą się z tradycją patrystyki greckiej; ta bowiem, mimo wszystko, jest nieco mniej reprezentowana w bibliografii i to nie tylko polskiej, a wpływ na to ma zarówno wielość wątków poruszanej problematyki i nierzadko niejasność wypowiedzi (jak np. w pismach Klemensa Aleksandryjskiego), jak i trudny język; w aktualnej bowiem sytuacji nauka języka greckiego nie znajduje właściwego miejsca nawet na studiach filologicznych, a cóż dopiero teologicznych; ten problem ciągle czeka na pozytywne rozwiązanie, na razie jednak kryzys ulega coraz większemu pogłębieniu. $\mathrm{Z}$ tym większym zainteresowaniem bierzemy do ręki publikacje, które opierają się na źródłach greckich, myślimy tu oczywiście

${ }^{3}$ Basile de Césarée, Homélies sur Hexaéméron, par Stanislas Giet, 2. édition augmentée, SCh 26bis, Paris 1968.

${ }^{4}$ Por. Sväte Písmo Starého i Nového zákona. Slovenský ústav svätého Cyrila a Metoda, Rím 1995. 
o pismach Ojców Kościoła, tym bardziej, że zawierają one często niezwykle ważne treści, które stanowily podstawę wielu orzeczeń dogmatycznych formulowanych na Soborach Kościoła Powszechnego.

Do tych pozycji należy bez wątpienia i omawiana praca (stanowiąca rozprawę habilitacyjną) ks. N. Widoka, związanego przez lata studiów z patrystyką Katolickiego Uniwersytetu Lubelskiego, a dziś będącego już samodzielnym pracownikiem Wydziału Teologicznego Uniwersytetu w Opolu. Już w samej nazwie pracy znajduje się wskazanie na jedno $z$ najistotniejszych pojęć $w$ teologii patrystycznej, a mianowicie pojęcie physis. Wokół tego też pojęcia będą się koncentrowały rozważania Autora, który podzielił swoją rozprawę na sześć rozdziałów, noszących następujące tytuły: Physis przed Grzegorzem z Nazjanzu, Physis kosmologiczna, Physis antropologiczna, Physis trynitarna, Physis chrystologiczna, Physis angelologiczna.

W I rozdziale (ss. 21-58) Autor dokonal przeglądu treści pojęcia physis w literaturze i filozofii greckiej, podkreślając, że należało ono do kluczowych terminów w tej twórczości. Duże znaczenie dla wyników badań miało i to, że Autor ukończył studia filologiczne, których przydatność właśnie w patrologii (a traktując szerzej - w teologii) znalazła raz jeszcze jednoznaczny wyraz. Po przedstawieniu charakterystyki słowa physis w literaturze przedchrześcijańskiej, Autor przeszedł do zaprezentowania go w księgach biblijnych, a następnie do ogólnej jego charakterystyki w utworach pisarzy wczesnego chrześcijaństwa. Podsumowując zaś stwierdzil, że ,słowo physis, tak bardzo popularne i rozpowszechnione w literaturze przedchrześcijańskiej, powoli, ale zdecydowanie zdobywało językowy status w literaturze chrześcijańskiej".

Przechodząc do twórczości samego Grzegorza, w II rozdziale (ss. 59-106) przedstawia analizę tego pojęcia w odniesieniu do świata przyrody, przy czym najpierw omawia ten problem całościowo, a następnie zatrzymuje się na poszczególnych jego częściach. Tutaj też pojawiają się nawiązania teologiczne, zaczerpnięte $\mathrm{z}$ twórczości Grzegorza, np. „świat to wielkie i slawne tworzywo, w którym Bóg się objawia”. Wypływa $z$ tego ważna teza, która nie zawsze znajdowała zdecydowanych adherentów wśród pisarzy wczesnego chrześcijaństwa, a mianowicie, że świat materialny jest boski, ponieważ od Boga pochodzi i jest miejscem, w którym się Bóg objawia. Dobrze się stało, że ks. Widok wyeksponował ten wątek, bo świadczy on o pozytywnej opozycji w kręgach teologów greckich do nurtu usiłującego widzieć w świecie jedynie lub przede wszystkim pierwiastek zła i domenę złego ducha.

W III rozdziale (ss. 107-172), traktującym o physis antropologicznej, spotykamy też ważne konstatacje, które są owocem dokładnej analizy trudnego przecież tekstu Grzegorza: chodzi tutaj m.in. o stwierdzenie, że physis oznacza ciało i duszę jako jedność dwóch różnych elementów. Doniosłość tej wypowiedzi rozumie każdy, kto wie, jakie były losy znacznie późniejszej dyskusji o formę i materię w odniesieniu do duszy i ciała człowieka. 
Głównymi częściami pracy, decydującymi o jej znaczeniu dla zrozumienia tak istotnego problemu teologii patrystycznej, jakim była nauka Ojców Kościoła o Trójcy Swiętej, są rozdziały IV i V. Rozdział IV (ss. 173-246) nosi tytul: „Physis trynitarna”. Autor pracy podkreśla, że Grzegorz używa bardzo precyzyjnie takich pojęć jak „Bóg” i „Trójca Swięta”, co ma szczególne znaczenie wobec licznych nieporozumień na tym tle w owych czasach. Swiadomość Grzegorza, odnośnie stwierdzenia: „czym w ogóle Bóg jest w naturze swej i w istocie, tego nigdy żaden człowiek ani nie zbadal, ani niech nie bada", dobrze świadczy o kapadockim teologu. W podobnym tonie wyrażal się on, gdy stwierdzal, ze „rozum ludzki nie jest w stanie zgłębić tajemnicy Boga”. Z tym też zgodna jest wypowiedź Grzegorza, że natura Boża jest niewypowiedziana i przechodzi wszelki rozum. Wymieniając te $\mathrm{i}$ inne właściwości natury Bożej Grzegorz okazuje się jednym $\mathrm{z}$ twórców nauki trynitarnej wczesnego chrześcijaństwa, $\mathrm{i}$ to $\mathrm{w}$ pracy ks. Widoka jest bardzo dobrze ukazane stanowiąc o jej niezaprzeczalnej wartości. W podsumowaniu rozdziału zwrócona została uwaga, że konotacje słowa physis w analizowanych tekstach spowodowały wyodrębnienie trzech zakresów tematycznych, w których ono oznacza: 1. Boga Trójjedynego, 2. Trójcę Świętą i 3. Osobę Boską. Podkreśla też Autor pracy, że wyszczególnione przymioty, którymi Grzegorz opisuje byt Boga, stanowią jedynie pewną ich ilość. Zdecydowana większość, to tak zwane przymioty negatywne, tworzące zrąb teologii apofatycznej, której Nazjanzeńczyk jest głównym przedstawicielem. Ks. Widok udowodnil również, że skoro physis oznacza samoistny byt, to liczba mnoga physeis, zastosowana w twórczości Teologa w celu przedstawienia nauki heretyków, powoduje pojawienie się trzech niezależnych jednostek bytowych, co w nauce trynitarnej jest oczywiście błędem.

W V rozdziale (ss. 247-262) zajął się Autor ukazaniem zastosowania słowa physeis w odniesieniu do Chrystusa. Rozdział ten zawiera wiele ważnych stwierdzeń odnoszących się do dyskusji wokół problemu dwóch natur w jednej Osobie Zbawcy. Grzegorz jednoznacznie opowiada się za obecnością w Chrystusie wcielonym dwóch elementów: każdy $\mathrm{z}$ nich oznaczony jest słowem physis, które wyraża jestestwo różniących się między sobą bytów. Ich jedność natomiast została wyrażona przez słowo Hen. W ogóle rozdział ten dostarcza bardzo wiele istotnego materiału dla kształtowania się pojęć dogmatycznych Soboru Efeskiego i Chalcedońskiego: praca ks. Widoka jest bez wątpienia pierwszą w dorobku polskich patrologów, która tak szczegółowo i rzetelnie eksponuje tę kwestię w odniesieniu do Grzegorza z Nazjanzu, a jak można przypuszczać, sądząc po bibliografii, może i w patrologii europejskiej.

Wreszcie w rozdziale VI (ss. 263-276) analizuje ks. Widok teksty kapadockiego biskupa pod kątem physis angelologicznej, gdzie stwierdza m.in.: „Mówca, relacjonując dzieje stworzenia, wskazuje na moment pojawienia się nowej rzeczywistości, którą jest «świat duchowy» (ho noetòs kósmos). Jest to sformułowanie, które jednak bliżej jej nie opisuje, dopiero w dalszej części 
wypowiedzi następuje w pewnej mierze konkretyzacja zapowiedzianej przez autora myśli. Ten świat duchowy został określony przez autora słowem physis" (s. 264). Okazało się, że i w przypadku świata duchowego słowo to gra kluczową rolę.

Książka ks. Norberta Widoka wypełnia część dotkliwej luki, jaką daje się zauważyć w badaniach patrystycznych w naszym kraju: obok obszernej pracy o Grzegorzu Teologu ks. Szymusiaka, mającej już niemal 40 lat, nie pojawiła się w Polsce żadna tak obszerna, a jednocześnie tak poważna rozprawa, jaką jest omawiana praca. Tym bardziej warta jest uwagi, że porusza kwestie niezwykle istotne dla zrozumienia kształtowania się nauki wiary i rzutuje na całą obowiązującą w Kościele Powszechnym doktrynę trynitarną. W moim przekonaniu jej odbiorcami, w niemniejszym stopniu niż patrologowie, winni być także badacze historii dogmatów, a stąd potrzeba jej szerokiej popularyzacji w kręgach polskich teologów. Praca jest godna wszelkiej rekomendacji i szerszej promocji w środowiskach naukowych, jak również i w studenckich kołach zainteresowań.

Jerzy Wojtczak-Szyszkowski - Warszawa

\section{Święty AUGUSTYN, Pisma o matżeństwie i dziewictwie, przeklad i komentarz zbiorowy, redakcja i wprowadzenie ks. A. Eckmann, Źródla i monografie TN KUL 245, Lublin 2003, Wydawnictwo Towarzystwa Naukowego KUL, ss. 392.}

Mając na względzie charakter otaczającej nas rzeczywistości, zupełne zeświecczenie obyczajów i kultury nie tylko materialnej, ale i duchowej naszego społeczeństwa - powinniśmy postawić sobie pytanie, czy potrafimy jeszcze w galimatiasie materialnego świata odnaleźć prawdy wiary. W obliczu tak ponurej rzeczywistości, przepełnionej marazmem, cierpieniem, zawiścią, kultem pieniądza, wydaje się, że opracowanie przez ks. prof. dr hab. A. Eckmanna Pism świętego Augustyna o matzenstwie $i$ dziewictwie, może stać się dla nas jedną z tych pozycji, które zawsze warto wziąć do ręki w chwilach zwątpienia.

Wartości, które są nam proponowane odnoszą się w przeważającej większości do kobiet, ale przecież to nie tylko na nich spoczywa odpowiedzialność za kształt świata. Dlatego nie tylko kobiety, młode dziewczyny, matki i żony powinny sięgać po tę książkę, ale i ci wszyscy, którzy współtworzą razem z nimi tę małą społeczność, jaką jest rodzina i ci, którzy w ferworze swych politycznych zamierzeń zapominają o tym, że rodzina jest podstawą prawidłowo funkcjonującego państwa. Rodzina właśnie jest jak małe państwo, jak państwo w państwie, o którego dobro powinniśmy zadbać w pierwszej kolejności. Możliwość zaś określenia właściwych priorytetów dają nam pisma św. Augustyna.

Na zawartość książki składają się: wprowadzenie pt. „Św. Augustyn o małżeństwie i dziewictwie” ks. Profesora A. Eckmanna (ss. 5-49), „Bibliografia” 